\title{
THE SINGAPORE CONSTITUTION AND ITS CRITICS
}

\author{
C L Lim*
}

\section{INTRODUCTION}

The latest book about governance in Singapore ${ }^{1}$ takes a different tack from recent works in the area; Professor Ho Khai Leong's The Politics of PolicyMaking in Singapore ${ }^{2}$ and, more recently, Professor Mauzy's and Professor Milne's impressive Singapore Politics under the People's Action Party. ${ }^{3}$ Even should the scholars themselves have rather different views, these latter scholarly works describe the workings of Government in Singapore through a keen and informed engagement with Singapore's current policies and institutional aspirations. Despite claiming close knowledge of the inner workings of Government, ${ }^{4}$ Dr Worthington takes, instead, an outsider's viewpoint from the outset. ${ }^{5}$ This is surprising enough for a book that seeks to describe the reality of Singapore's governance, but Worthington also expects

* Faculty of Law, National University of Singapore. I am grateful to a number of people: M Hor and G Bell discussed some of my views with me; Mrs T Yee made her lucid analysis of the Pointe Gourde principle available to me in manuscript form; and A Briggs of St Edmund Hall, Oxford University who pointed the way to the Petrotimor case. My able student, Mr J Loy (J D candidate, New York University) also deserves special mention for it was he who spotted quite a few infelicitous expressions and turns of phrase in the final draft and took me to task. The views expressed herein are mine alone, however, and so too are any errors or omissions.

${ }^{1} \mathrm{R}$ Worthington Governance in Singapore (New York: Taylor Francis, Inc., 2002). Dr Worthington is the Executive Director of the Philippines Australia Governance Facility in Manila and an Associate of the Asia Research Centre of Murdoch University, Perth, Western Australia.

${ }^{2}$ H Leong The Politics of Policy-Making in Singapore (Singapore: Oxford University Press, 2000).

${ }^{3}$ D Mauzy and R Milne Singapore's Politics under the People's Action Party (London: Routledge, 2002).

${ }^{4}$ See $n 114$ at 259.

${ }^{5}$ As Worthington states: "This is a study of the core executive in the context of the Singaporean hegemonic state” at p 3. For his research paradigm/methodological framework, see, generally, Chapter 1 'Governance, Singapore and the Hegemonic State'. His references to feedback from (anonymous) respondents are a familiar feature in his footnotes. 


\section{THE DENNING LAW JOURNAL}

the initiative for the reforms which he recommends to be taken specifically by Singapore's ruling political party. ${ }^{6}$ There is also much discussion of individual personalities, but this is sought to be justified by an academic need to supplement an underlying thesis of political hegemony with an empirical study of policy and personal networks in Singapore. ${ }^{7}$

What could have otherwise been highly valuable is Worthington's attention to Singapore's legal institutions and practices, including an entire chapter on the judiciary. ${ }^{8}$ An earlier version of this chapter had previously been published

\footnotetext{
${ }^{6}$ Worthington, above n 1 , see pp 245, 249-250.

${ }^{7}$ Worthington, above $\mathrm{n} 1$.
}

${ }^{8}$ Worthington, above $\mathrm{n} 1$ at 288. As he puts it: "Nowhere in the Singaporean literature do we find the judiciary within the core executive". The other substantive chapters include a study of the relationship between the executive and the legislature, and studies of the Singapore civil service, and government intervention in the market. While the first is also relevant to readers from a public law viewpoint, there is hardly anything new there, and I have chosen to forego discussing it in any detail for the most part. In general terms, however, Worthington's study draws from Professor A Harding's insights about the ultimately Westminster character or style of the Singapore constitutional system (at pp 12-14), prizing de facto legislative supremacy and the practice of cabinet government with its attendant implications for the executivelegislative relationship; A Harding 'Parliament and the Grundnorm in Singapore' (1983) 25 Malaya Law Review 351. The perspective taken is itself relatively uncontroversial and is widely recognised in Singapore constitutional law scholarship today; see the discussion in K Tan 'The Evolution of Singapore's Modern Constitution: Developments from 1946 to the Present Day’ (1989) 1 Singapore Academy of Law Journal 1, at 17-23; T Li-ann, 'The Elected President and the Legal Control of Government' in K Tan and L Peng Er (ed), Managing Political Change in Singapore: The Elected Presidency (London: Routledge, 1997) 100, n 12 below at 136-137; V Winslow 'The Election of a President in a Parliamentary System', in Tan and Lam, ibid, 88, at 88-91; and T Li-ann, 'Recent Constitutional Developments: of Shadows and Whips, Race, Rifts and Rights, Terror and Tudungs, Women and Wrongs' [2002] Singapore Journal of Legal Studies 328, at 330. This is then coupled with Worthington's more general methodological pre-occupation which is also dependent on insights provided by studies in the 1970s of the role of elites in the Singapore polity in the pioneering works of $\mathrm{C}$ Chee and $\mathrm{P}$ Chen, see $\mathrm{C}$ Chee, 'Politics in an Administrative State: Where Has the Politics Gone?' in S Meow (ed), Trends in Singapore (Singapore: ISEAS/Singapore University Press, 1975) and P Chen 'The Power Elite in Singapore' in P Chen and H Evers (ed), Studies in ASEAN Sociology (Singapore: Chopmen, 1978), 73. In large part, as Thio's 2002 critical study shows, the constitutional debate in Singapore has moved further afield compared with the issues 


\section{THE DENNING LAW JOURNAL}

as a law review article. ${ }^{9}$ In it, Worthington contests the findings of the World Competitiveness Report, which has consistently ranked Singapore's legal system at, or very near, the top of the pile globally. According to Dr Worthington, "this survey, based on rankings by private sector executives, almost all of whom do not live in Singapore and have no interest or genuine knowledge of the political system, only genuinely reflects the accumulated ignorance of the respondents rather than any genuine knowledge of the Singaporean legal system". ${ }^{10}$ Elsewhere, he says that he has it on good authority that another scholar who has written widely on policy-making in Singapore simply does not have the kind of access to Singapore's government decision-makers that he has. ${ }^{11}$ Worthington, on the other hand, claims a twentyyear scholarly interest in the governance of Singapore, a stint with the Institute of Southeast Asian Studies, and, in his own prefatory words, personal status as a "a critical friend" of Singapore. ${ }^{12}$

What Worthington claims about judicial dynamics in Singapore and the separation of constitutional powers and functions between the executive and the legislature in light of Singapore's Westminster-style system of government go towards some important and long-standing questions concerning the nature of Singapore's "living" constitution. In this, his critique presents an opportunity to set the record straight in respect of some long-standing criticisms of the

which Dr Worthington's book deals with and the reforms he proposes. See also, for the debate about the future of the relationship between the State and civil society, S Tay, “'The Future of Civil Society. What Next?' in D de Cunha (ed), Singapore in the New Millenium: Challenges Facing the City-State (Singapore: ISEAS, 2002), 69, and S.C. Tay, 'Island in the World: Globalization and Singapore's Transformation' in Southeast Asian Affairs 2001 (Singapore: ISEAS, 2002), 279, at 287-292. In respect of the other chapters, there is arguably little that is startlingly new either. On the role of the Government in the marketplace, see S Haggard and L Low, 'State, Politics and Business in Singapore' in E Gomez Political Business in East Asia (London: Routledge, 2002), 301. As for Worthington's chapter on the civil service, see also Ho, see n 2. I have already noted the importance of Mauzy's and Milne's latest work, see n 1.

${ }^{9} \mathrm{R}$ Worthington 'Between Hermes and Themis: An Empirical Study of the Judiciary in Singapore’ (2001) 28 Journal of Law \& Society 490.

${ }^{10}$ See n 107.
${ }^{11}$ See n 114 at 259.
See n 8. 
Singapore Constitution whose importance go well beyond the publication of Worthington's book.

\section{DIFFERENT STROKES FOR DIFFERENT FOLKS}

Worthington, in common with Singapore's critics, rests his argument on a number of notions characteristic of standard rule of law thinking, but given flesh by a number of associated ideals and comparative practice inherited elsewhere. Amongst these are the political independence of the judiciary, and Dicey's view ${ }^{13}$ that the rule of law means, amongst other things, that the "ordinary law of the land" will be applied by the "ordinary courts of the land", and not by special tribunals or what Worthington calls "para-judicial structures". However, to provide more concrete expression to these ideals, Worthington also weaves certain inherited practices into these. Examples include the fierce independence of the English Bar, and what permanent judicial tenure means, according to him anyway, in other jurisdictions. He also tends to hold these ideals higher than what our actual experience of comparative institutional arrangements elsewhere would truly suggest.

Admittedly, I found it difficult to see what he is getting at with his discussion of judicial appointment and tenure in Singapore. We know the constitutional rules on this, the corresponding practice here in Singapore, and who the decision-makers are, in institutional terms, in respect of judicial appointment and tenure. Yet I cannot see any basis for his criticisms if we take, for example, the United Kingdom or the United States as benchmarks. ${ }^{14}$ However, his claims are not simply theoretical, by which I mean the construction of some sort of abstract argument as to why we should hold the ideal of judicial tenure higher than what our actual experience tells us. He goes on, instead, to pick and choose amongst comparative legal traditions,

\footnotetext{
${ }^{13}$ A Dicey Introduction to the Study of the Law of the Constitution (Indianapolis: Liberty Fund, 1982) at 110, and 114-115, in particular.

14 See $\mathrm{n} 1$ at 106 . Worthington remarks on the constitutional provisions, followed by the remark that "tenure in the subordinate courts is even more precarious" (my emphasis). To offer another example of this sort of underlying methodological flaw, Worthington cites section 27 of the Government Proceedings Act (Cap 121) which 'prohibits a court from granting an injunction against the government'. Yet he fails to tell us how this is any different from the equivalent provision in England, representing the position at common-law, namely, section 21 of the Crown Proceedings Act 1947; see $n 91$ at 302 .
} 


\section{THE DENNING LAW JOURNAL}

demonstrating, for example, a strong preference for judicial appointments from an independent practising Bar. While he acknowledges that detractions from practices in other jurisdictions may be justified, this is to be considered so only where a rule of law culture in the sense which he approves of is also present (i.e. not in Singapore). ${ }^{15}$ This, in substance, is the basis for his criticism of the discontinuance of appeals to the Privy Council as an executive gambit, ${ }^{16}$ a criticism that has been widely heard elsewhere.

Worthington cites Professor Andrew Phang on the same page, but neglects to mention that it was Phang who had argued, convincingly, against appeals to the Privy Council some years before the Judicial Committee (Repeal) Act of 1994. ${ }^{17}$ In this, he ignores the fact that the English courts had themselves struggled for decades with achieving the right balance in respect of the workings of the doctrine of precedent in English law. For the highest Singapore court then to be bound both by itself and by a tribunal sitting thousands of miles away would strike most people as being somewhat ludicrous today. ${ }^{18}$ To

\footnotetext{
${ }^{15}$ See n 1 at 111 (Worthington's comments in respect of the Pennsylvania judicial system).

${ }^{16}$ See $\mathrm{n} 1$ at 119 .
}

${ }^{17}$ A Phang, VRajah and K Tan 'The Case for a Re-Appraisal and Restatement of the Doctrine of Stare Decisis in Singapore - An Overview’ (1990) 6 Law Society's Journal 22. See also A Phang, V Rajah and $K$ Tan 'The Case for a Re-Appraisal and ReStatement of the Doctrine of Stare Decisis in Singapore' (1990) 2 Malayan Law Journal lxxxi, xcvii and cxiii (in three parts). The argument had been made even earlier than that, see $\mathrm{H}$ Meng 'The Privy Council as Court of Last Resort in Singapore and Malaysia: 1957-1983' in A Harding (ed), The Common Law in Singapore and Malaysia: A Volume of Essays Marking the $25^{\text {th }}$ Anniversary of the Malaya Law Review (Singapore: Butterworths, 1985), 75 at 113-114.

${ }^{18}$ It was not until the abolition of all appeals to the Privy Council in 1994 that the Court of Appeal in Singapore adopted the sensible approach of England's House of Lords since 1966, which after thirty years of judicial criticism in England finally departed from a rigid English common-law rule that had its origins in the middle of the nineteenth century. Namely, that it would be advantageous for the highest court in the land to have the power to depart from its own previous decisions; see Practice Statement (Judicial Precedent) of the Court of Appeal [1994] 2 SLR 689; compare (the English) Practice Statement [1966] 1 WLR 1234. For judicial criticism in England of the practice of the House of Lords prior to 1966, see Lord Wright 'Precedent' [1944] Cambridge Law Journal 118; Lord Reid's speech in Midland Silicones Ltd v Scruttons Ltd [1962] AC 446 (HL) per Lord Reid at 475, Lord Denning's Romanes Lecture of 1959 'From Precedent to Precedent' which is quoted in Lord Denning The Discipline of 


\section{THE DENNING LAW JOURNAL}

compound that by saying that while New Zealand and Australia may be justified in doing the same, but that Singapore would not, is therefore also curious, yet Worthington sees nothing wrong with putting down the argument in print. ${ }^{19}$ To some, the argument would, unfortunately, be virtually indistinguishable from a self-serving argument widely-heard before events were overtaken by the United Nations decolonisation process. I cannot help but think, in respect of what Ali Mazrui has termed a "pigmentational" theory selfdetermination, that Worthington's stance amounts ultimately to saying (if I might put it bluntly) that the natives would simply require tutelage over an extended period, and therefore cannot be trusted with their immediate and unconditional liberty. It seems that no difference may otherwise be drawn between the reasons that would commend themselves in respect of the abolition

Law (London: Butterworths Tolley, 1979), at 291 et seq. Previously, the Court of Appeal in Singapore was bound, generally, to observe its previous decisions with limited exceptions under the rule in Young v Bristol Aeroplane Ltd [1944] KB 718, CA as well as those of the Judicial Committee; the speech of Wee Chong J in Mah Kah Yew $v$ Public Prosecutor [1971] 1 MLJ 1. While in England there had also been vigorous judicial debate in a spirited campaign led by Lord Denning with respect to whether even the English Court of Appeal ought to be bound to the rule in Young v Bristol after the Practice Statement of 1966, and this had led to a series of spectacular decisions, prior to the Judicial Committee (Repeal) Act, Act 2/94. Nevertheless, Singapore, amazingly, had no highest court of its own. That this could have persisted into the 1990s is something quite remarkable in itself, considering that the Singapore legal system's closest counterpart in many ways, that of Malaysia, had earlier abolished recourse to the Privy Council. Little wonder then that law teachers here at the National University of Singapore had counselled discontinuance of recourse to the Privy Council years before Parliament acted. Yet now we have Dr Worthington telling us, years later, that the reason for that legislative move was somehow political, as if there were not somehow good enough reason for all to see. Well, legislative reform is political. If we are then talking about the stronger sense of the word "political", I would argue that abolition was, if anything, delayed by pragmatic political considerations, as well as considerations of expediency, having to do, one would have thought, with Singapore's precarious beginnings, it's troubled early history, and the passage of time required to ensure investor confidence during the earlier years, see, for example, the speech of the then Prime Minister in Singapore Parliamentary Debates, Official Record, March 15 1967, cols 1294-1295.

${ }^{19}$ See $n 1$ at 116-117. 


\title{
THE DENNING LAW JOURNAL
}

of continued recourse to the Privy Council in New Zealand's or Australia's case, and the (same) reasons for doing so in Singapore. He says this: ${ }^{20}$

\begin{abstract}
"The abolition of appeals to a non-Singaporean tribunal is, in itself, no cause for concern; New Zealand acted in 1996 to do likewise, as has Australia. The principal concern is that the indigenous judicial system be sufficiently mature to defend the rule of law, maintain the independence of the judiciary and, at the most basic level, be able to provide balance in the exercise of state power over citizens.”
\end{abstract}

If in Australia and New Zealand the courts there would always decide as the Privy Council would, then abolishing recourse to the Privy Council would, presumably, be superfluous. Yet even here, matters are not reflected in the singularity of Dr Worthington's logic. The situation faced by Singapore was described thus in $1985:^{21}$

“... the Privy Council has continued to exercise a very significant amount of influence on legal development in Singapore and Malaysia even after independence. High reversal rates (insofar as reversal indicates legal development in a direction against the will of the local appellate court) are but one index of the reality of this influence. And, even when the Privy Council dismissed an appeal, it could still make law in the process...As for the great bulk of cases which did go to the Privy Council, the doctrine of stare decisis ensured that in dispensing justice local courts applied the law as expounded by the Privy Council...In the last ten years the number of Privy

\footnotetext{
${ }^{20}$ See $n 1$ at 116 -117 (footnotes in the original omitted). To my knowledge, however, the Privy Council issue, in the form of the Supreme Court Bill, is still being debated in New Zealand; the National Government having decided to retain appeals to the Privy Council in 1997. The right of appeal to the Privy Council from Australia was effectively abolished by the Australian Privy Council (Limitation of Appeals) Act of 1968 and the Privy Council (Appeals from the High Court) Act of 1975 in the case of the Commonwealth courts, and by the Australia Act of 1986 in respect of the State courts.

${ }^{21}$ Chan see $\mathrm{n} 17$ at $112-114$.
} 
Council appeals has been on the rise. Privy Council appeals will soon be history in Malaysia, but for Singapore, this trend is likely to continue. A dilation in the volume of appeals will present the Privy Council with even more opportunities to shape legal development in Singapore...For Malaysia, the final extinction of Privy Council appeals and the assumption of full judicial sovereignty is an expression of Malaysian nationalism...For Singapore, to borrow the words of Lord Normand, "the continuance of the appeal or its abolition...is a question of convenience and not one of fundamental importance"... perhaps the Malaysian abolition presents an appropriate occasion for Singapore to re-examine her reasons for retaining Privy Council appeals.”

Much in the same vein, Worthington also criticises the institutionalisation, in Singapore, of arbitration and other means of alternative dispute resolution. The underlying policy here, it would have been thought, is that this is precisely what a modern mercantile society such as Singapore's would be ideally suited towards. Dr Worthington, however, sees a conspiracy. He says that that alternative means of dispute resolution in Singapore are just another way of shielding the judiciary from criticism. ${ }^{22}$ Yet he does not tell us why he thinks so, and we cannot therefore engage him here. His point, however, is a general one, which is that, all-in-all, a strong measure of discretion is not a part of the Singapore judicial landscape, and we can perhaps say something about this.

\section{ON TENURE AND JUDICIAL INDEPENDENCE}

His criticisms are put across most clearly in respect of judicial tenure. For some, that Singapore has judges who are past retirement age does not automatically mean, for example, that Singapore's judiciary thereby lacks independence, unless one is already inclined to believe that anyway. The classic choice in superior court appointments is that between having a retirement age at all, and not having one. Dr Worthington disagrees, and his argument is threefold. First, judicial appointments at superior court level still rely too heavily on the Singapore legal service, which, being part of the civil service is

${ }^{22}$ See $n 1$ at 119. 
therefore to be considered a part of the executive. ${ }^{23}$ Secondly, Singapore's Court of Appeal judges are, as a matter of deliberated policy, well into their seventies, and other Supreme Court judges in their sixties, and because of this, they are past retirement age, which makes them thereby dependent on the executive for continuing in these judicial positions. ${ }^{24}$ His third point is that the first two are intentionally corrosive of the independence of Singapore's Court of Appeal. ${ }^{25}$

We are all certainly familiar with the theory underlying these arguments; namely, that we should not countenance the absence of permanent judicial tenure under any circumstances. True, Singapore has not been absolutist in adhering to Hamilton here, and has sometimes kept judges on the bench despite having a retirement age. It is a great leap, however, to suggest that this amounts to an intentional corrosion of judicial independence, and ignores a further aspect of Hamilton's argument, which is that "there can be but few men in society, who will have sufficient skill in the laws to qualify them for the stations of judges." 26 Or indeed, that the judiciary in Singapore is consequently lacking in independence.

Compare a recent Court of Appeal decision on the Land Acquisition Act (Cap 152). The Act goes to the heart of a long-held land-use policy in landscarce Singapore. The case resulted in a split judgment (two to one) in favour of the Government, and it says something of Dr Worthington's thesis. In $\mathrm{Ng}$ Boo Tan $^{27}$ the dissenting judge (The Honourable Chao Hick Tin J.A.) was formerly a widely respected officer in the career legal service, is far from being in his sixties even now let alone in 1998 (Dr Worthington's cut-off date for his study).

What then of the Chief Justice's majority opinion in that case? The Chief Justice of Singapore is, after all, the only judge on the bench of Singapore's highest appellate court who is over the age of retirement, a state of affairs wholly opposed to Hamiltonian logic. Admittedly, there is a widespread and accurate general perception that the incumbent Chief Justice has a distinctive

\footnotetext{
${ }^{23}$ See $n 1$ at 109 .

${ }^{24}$ See $n 1$ at 110 .

${ }^{25}$ See $n 1$ at 110 .

${ }^{26}$ A Hamilton The Federalist No. 78 (Connecticut: Wesleyan University Press, Jacob E. Cooke ed 1961), 521.

${ }^{27}$ Re No 2091D Upper Paya Lebar Road Elling Court, $\mathrm{Ng}$ Boo Tan v Collector of Inland Revenue [2002] 4 SLR 495. See T Yee 'Is there any Pointe?' [2003] Singapore Journal of Legal Studies 262.
} 


\section{THE DENNING LAW JOURNAL}

judicial turn of mind, but this is not to say, however, that it is not also an independent judicial turn of mind. The truth is that Hamilton advanced two principles, not one. The first principle is that judges should have permanent tenure, and this suggests that a nation should choose either to retire its judges if past retirement age, or to retire the stipulation itself of a retirement age. A second principle, however, which Worthington neglects, was that we should also have the best people. What is to occur then in case of conflict between the two Hamiltonian principles? We do not know. In Singapore's case, the aim has been to have "the best people" and a retirement age, and if need be, to stick to having "the best people" despite their age.

\section{THE ATTORNEY-GENERAL'S CONSTITUTIONAL ROLE}

This brings me to a particular danger of post-colonial empirical sociological analyses of this sort; namely, a propensity to ignore the fact that indigenous legal phenomena cannot be fully understood in isolation from the indigenous legal concepts in play. The governing legal concepts circumscribe and define the meaning of such legal phenomena. Notions such as that of a "core executive", or "hegemony", and so on are sociological concepts after all. ${ }^{28}$ In some circles in legal-sociological analysis today, it is assumed that you can actually explain the law better by applying purely extraneous, non-legal, concepts to its study. ${ }^{29}$ A small example can be offered here. A police practice

\footnotetext{
${ }^{28}$ At the most basic level, the issue is that of whether we can better understand what it means to have law and legal institutions by speaking from within the terms of the law and from within the boundaries of the meaning of our legal concepts, rules, principles, practices and institutions than if we were to jettison the "lawyers' understanding" in the first place. Putting aside the radical leftist pursuit of viewing legal phenomena through the concept of hegemony, I would mention G Parry's seminal work on elites in his Political Elites (London: Allen \& Unwin, 1969). In it, he discusses the relationship between elites and the demands of democratic society. In the terms used by Parry, however, Dr Worthington's conception of what it means to study elites would be very much in the radical democratic camp, and ignores the difference between studying elites in a polity, and the very different use of the word to allege elite domination. Worthington is concerned only with the latter. In the different parts of this short review, I have tried to show that Worthington, however, tends to see elite domination through the simplest things, and his work therefore lacks basic descriptive rigour.

${ }^{29} \mathrm{H}$ Hart The Concept of Law (Oxford: Clarendon, 1961) at 120-150. This is the modern version of what Hart argued cogently against in his attack of so-called "rulescepticism” (ie that legal rules are, in themselves, meaningless categories). See
} 


\section{THE DENNING LAW JOURNAL}

of interviewing battered women in the company of the spouse or partner may lead to a misleadingly high statistical probability of findings of "No, officer, you must be mistaken, I fell" (ie a record that no crime has been committed, and therefore no further criminal investigation would be warranted). Be that so, in the domestic violence example, everyone knows that there has been no criminal either, in the legal sense, if there has been no conviction, which while being the sociologist's complaint, remains nonetheless the lawyer's truth. ${ }^{30}$ Yet

Professor M Freeman's useful introduction for those wholly unacquainted in Lloyd's Introduction to Jurisprudence (London: Sweet \& Maxwell, 1994), at 537-550.

${ }^{30}$ I have selected this example from N Walker Crime and Criminology: A Critical Introduction (Oxford: Oxford University Press, 1987) at 21. So far as Dr Worthington is concerned, however, he should simply heed Professor Cotterell's warning that “...in confronting legal discourse sociology confronts another enterprise of interpretation whose power (social and political) must be recognized. The sociological study of law is thus, above all, a study of (legal) forms and mechanisms of power and of the power of (legal) ideas in controlling and shaping social life”; see R Cotterell Law's Community: Legal Theory in Sociological Perspective (Oxford: Clarendon, 1995) at 69). Another leading authority who takes the sensible view that the explanatory power of legal situations by legal rules cannot be dismissed in the way Worthington seeks to do is Professor G Teubner (ed) Juridification of Social Spheres: a comparative analysis in the areas of labour, corporate, antitrust and social welfare law (Berlin: de Gruyter, 1987), and G Teubner Law as an Autopoietic System (Oxford: Blackwell, 1993) at 109. Across the Atlantic, Professor B Tamanaha has this to say: 'It is time for socio-legal studies to get back to its scientific basics, to get back to impartial and disinterested investigation, to give up the impotent politics and the debunking anti-law attitude' see B Tamanaha Realistic Socio-Legal Theory: Pragmatism and a Social Theory of Law (Oxford: Clarendon, 1997) at 254-255. I have gone into these citations for the benefit of those who are not familiar with socio-legal studies, and hope those who are will excuse me. I simply do not want there to be any mistake that what Dr Worthington has embarked upon is not what socio-legal studies looks like even where we include the more radical (because "rule-sceptical") strands of thought in the movement; see, for example, R Unger 'The Critical Legal Studies Movement' (1983) 96 Harvard Law Review 563. For those uninitiated, the interdisciplinary extent of some radical scholarship can, however, be startling. The search is for the meaning of our legal terms and institutions elsewhere than within the areas of meaning provided by these terms and institutions themselves. This is perhaps best exemplified in Anglo-American legal scholarship in some of the work of the British Critical School, of which see, for example, P Goodrich Languages of Law: From Logics of Memory to Nomadic Masks (London: Weidenfeld \& Nicholson, 1990) and C Douzinas, R Warrington and S McVeigh Postmodern Jurisprudence: The Law of Text in the Texts of Law (London: 


\section{THE DENNING LAW JOURNAL}

this example remains relatively straightforward. Things are less straightforward when we are also comparing legal cultures for much may then depend on a range of substantive evaluations. A good example lies in the AttorneyGeneral's role which differs vastly across the various jurisdictions that employ the institution. In Singapore, the Attorney-General is critically different from the position in the United States or indeed the United Kingdom for the role and function of the Attorney-General is specified in the Singapore Constitution.

Perhaps the most notorious criticism has been of the Attorney-General's opinion in respect of a highly-charged political affair in 1997. This, in my view, has been the subject of much misunderstanding, and provides an excellent casestudy of how the institution has actually fared in the cross-fire of political controversy. The legal question there was whether it would have been an offence under the Parliamentary Elections Act (Cap 218) for an "unauthorised person" (amongst others, the Prime Minister of Singapore) to have entered and been present in a polling station. The answer given to that question by the Attorney-General was that no offence would have been committed as such, simply because the Act, when strictly construed in light of the question, dealt only with activities outside polling stations. Dr Worthington disagrees: "Apparently the alleged miscreants used top secret MINDEF technology and beamed into the polling stations Star Trek style, thus not crossing the 200 metre perimeter!" ${ }^{31}$ However, the legal point at hand, which is plain upon reading the Attorney-General's published opinion and the Act in question, ${ }^{32}$ is that the Act makes it an offence to loiter outside a polling station within a radius of 200 metres. There is no ambiguity here. The question put to the Attorney-General, however, was not whether anyone was loitering outside the polling station (presumably no-one was). The Act does not make it an offence to be present inside a polling station without authority. How one gets there is legally irrelevant for the patently sensible reason that the Act aims only to deal with a risk of undue voter influence or harassment outside the polling station, and within 200 metres of the polling station. The rationale for the terms of the Act was, moreover, quite clear. Unlike the situation inside polling stations, there

Routledge, 1991). Key members of the British school had originated from Lancaster University's Law Department and thereafter played a crucial role in establishing the law school at London University's Birkbeck College.

${ }^{31}$ See $n 123$.

${ }^{32}$ The Hon. Chan Sek Keong published in the Singapore Parliamentary Debates, Official Record, Vol 67, 30 July 1997 at cols 1417-1424. The opinion is cited by Dr Worthington in $\mathrm{n} 112$ at 304. 


\section{THE DENNING LAW JOURNAL}

would be no officials and election agents present outside. Hence, the Act deems there to be no risk within polling stations as such, but only outwith. In the case of persons inside polling stations, the Act only says that any person who misconducts himself in the polling station, or fails to obey the lawful orders of the presiding officer may be removed by a police officer under the orders of a presiding officer. In fact, an offence is only committed, but not under the Act, if at that point, such a person refuses to leave the polling station, as that person would then be obstructing a public servant in the exercise of his duty, this last being an offence under the Penal Code (Cap 224). It is hard to see which part of all this would therefore give rise to difficulty, aside from the fact that the legal question had an inescapable political dimension due to the fact that it was the Prime Minister himself, amongst others, who was said to have been present in a polling station on Election Day. ${ }^{33}$

${ }^{33}$ Had Worthington simply consulted the Singapore Parliamentary Debates, Official Record, see n 33 above, for the A-G's Opinion and noted the source cited in n 112 at 304 of his book, he would also have benefited from the explanation, in layperson's terms, given by the Hon Minister for Law Professor S Jayakumar at cols 1342-1344 in that same volume. Instead, Dr Worthington cites the Parliamentary Reports for the subsequent year where he disagrees with the explanation given in response to an opposition question in Parliament by the Minister of State for Law. The Minister of State had explained that the A-G is not a Member of the Executive, see n 115 at 304 and the accompanying text. I shall have something more to say below about Dr Worthington's misunderstanding of what Art 35 of the Constitution of the Republic of Singapore means. I must also mention here that Dr Worthington is not alone in his view. Aside from the opposition party that had expressed its dissatisfaction with the Opinion, my colleague Dr T Li-ann has been equally critical. According to Dr Thio: '...given the hierarchical stratification of Singapore society, it is unlikely that voters within a polling station will be unaffected by so august a personage as the PM and his two DPMs. Nor can one envisage, without scepticism, bureaucrats serving as election officers telling the PM to leave to prevent voter intimidation'; T Li-ann, 'The Right to Political Participation in Singapore: Tailor-Making a Westminster-modelled Constitution to Fit the Imperatives of “Asian” Democracy” (2002) 6 Singapore Journal of International \& Comparative Law 181 at 216. While this is a more sophisticated argument than Dr Worthington's, it nonetheless assumes (1) a certain character trait that the ordinary Singaporean ought to possess (which would have been a peculiar assumption indeed on the Attorney-General's part in rendering a formal opinion) and (2) that the Prime Minister and two other distinguished cabinet members had somehow had not been conducting themselves within the meaning of the Act (something which no-one suggests). 


\section{THE DENNING LAW JOURNAL}

I am compelled to say a little more to further illustrate my point, not only because of the misleading account given of the Attorney-General's role in various other places by Dr Worthington, but also because that role is also widely misunderstood elsewhere, even by Singapore legal scholars. ${ }^{34}$ Under the Constitution, the Attorney-General is the Government's legal advisor. ${ }^{35}$ According to Worthington's reading of the Singapore Constitution, however, since the relevant provision appears in that part of the Constitution dealing with the executive branch, the Attorney-General must therefore be a part of the executive branch. ${ }^{36}$ He thereby fails to convey what, in Singapore, is a point of constitutional law of some considerable practical importance that, moreover, has benefited from a good airing in Parliamentary debate. ${ }^{37}$

\footnotetext{
${ }^{34}$ For an experienced Singapore scholar who has, likewise, taken the view that the A-G is "technically part of the Executive", see M Hor 'The Independence of the Criminal Justice System in Singapore’ [2002] Singapore Journal of Legal Studies 497, n 60. In addition to the erroneous interpretation of the Constitution which Dr Worthington offers at 123, see also 106-107, 109, 111, and 113, n 78 at 301, n 105 at 317 and n 83 at 324. He is also grievously wrong in what he says about the Subordinate Courts Act (Cap 321) in n 105 at 317.

${ }^{35}$ Art 35 Constitution of the Republic of Singapore.

${ }^{36}$ Worthington says: 'One of the interesting associated outcomes of this conflict was a statement by Associate Professor $\mathrm{H}$ Kee during parliamentary debate, rejecting the view that the A-G is a member of the executive, and asserting that this office provides independent advice to the executive, despite the office being created in Chapter Two of the constitution which establishes the executive' at 123.

${ }^{37}$ See the Singapore Parliamentary Debates, Official Record, Vol 68, 14 January 1998, cols 81-82 (Mr L Khiang), 86 (Ass Prof H Kee), and 101 (Mr J Jeyaretnam). Mr Jeyaretnam's question was, therefore, probably at cross-purposes with the explanation in Parliament given by the Minister of State for Law. Compare also, for what I think is an example of the proposition that 'the Attorney-General is a member of the Government' in a weak architectural sense, Singapore Parliamentary Debates, Official Record, 29 May 1989, col. 149 (where the issue of prosecutorial discretion arose in a foreign policy context). Another misconception from the layperson's point of view and which also received the benefit of debate during that Parliamentary sitting, was the relationship, if any, between a judicial pronouncement and an opinion of the A-G; Singapore Parliamentary Debates, Official Record, Vol 68, 14 January 1998, cols 81-82 (Mr L Khiang). In addition to the explanation given by the Minister of State for Law which is discussed below at $n \mathbf{5 1}$, the A-G's opinion is typically given beforehand, but, like a judicial pronouncement, an opinion is, however, distinct from a brief. An opinion is a 'written document in which an attorney provides his or her understanding of the
} 


\section{THE DENNING LAW JOURNAL}

A distinction is required at the outset between the sense or meaning which Dr Worthington's argument suggests when he says that the Attorney-General is a part of the executive branch, and the substantive point which he seeks to convey with that interpretation. I view the former proposition to be a proposition in a significantly weaker sense than the latter. What Dr Worthington seems unaware of is that the two senses of the proposition part company at a critical juncture in his chain of reasoning. While Article 35 locates the office of the Attorney-General in the executive branch as a matter of constitutional architecture (the "weak sense" of the proposition), the Constitution envisages that the Attorney-General has certain powers and functions which are wholly at odds with Dr Worthington's suggestion that the Attorney-General is, in terms of the force or substance of the constitution, a part of the policy-making apparatus (the "strong sense" of the proposition). Two features matter in drawing this important legal distinction between the issue of constitutional architecture, which is neutral in substantive legal and constitutional terms, and the stronger sense in which Dr Worthington means to

law as applied to assumed facts' whereas a brief is a 'written statement setting out the legal contentions of a party in litigation' or a 'document prepared by counsel as the basis for arguing a case': Black's Law Dictionary,(St Paul Minnesota: West, $7^{\text {th }}$ ed, 1999) at 1120 and 186 respectively. Likewise, there is almost certainly a conceptual distinction between the case where the A-G renders a formal opinion and where he acts for the Government in civil proceedings. I say it is a "conceptual” distinction only as, in practice; the opinion-giving and representational functions should both consist of the same legal viewpoint as a matter of constitutional principle. There could not arise a conflict here inasmuch as the A-G's advice is plain even if the request for an opinion were to be couched in terms of a request for a legal argument in support of the Government. This is illustrated vividly in Sir R Manningham-Buller's response to a request for legal advice by the Foreign Secretary during the Suez crisis: 'On what is known to me, I am unable to devise an argument which could purport to justify in international law either our demand that [Egypt] who had in no way threatened our nationals should withdraw her forces from a part of her own territory which she is engaged in defending or the threat to occupy her territory by armed forces should she fail to accede to that demand' quoted in J Griffith Judicial Politics since 1920: A Chronicle (Oxford: Blackwell, 1993), at 72 (my emphasis). As it turned out, the English A-G was thereafter excluded from the usual advisory channels for the remainder of the affair; see L Johnman's fascinating 'Playing the Role of Cassandra: Sir Gerald Fitzmaurice, Senior Legal Advisor to the Foreign Office’ in S Kelly and A Gorst (ed) Whitehall and the Suez Crisis (London: Frank Cass, 2000) 46. 


\section{THE DENNING LAW JOURNAL}

convey the proposition and which is not simply architectural. ${ }^{38}$ The first has to do with the constitutionally prescribed method for the appointment and terms of tenure of the Attorney-General, and the second with certain pragmatic constitutional constraints in the fulfilment of the Attorney-General's functions. In both cases, I shall confine my remarks to the legal advisory role of the Attorney-General under the Constitution for there is no quarrel in respect of the constitutionally independent position of the Public Prosecutor. ${ }^{39}$

We can see from the express constitutional terms governing the appointment of the Attorney-General in Singapore that, unlike the situation in the United States for example, which some distinguished commentators have confessed is highly unsatisfactory, ${ }^{40}$ the Singapore Constitution is not silent in terms of there being any written law on the manner and method of appointment of the Attorney-General. Against the background of Federal-State rivalry in the formation of the United States, it was simply assumed, in the face of such silence in written law, that the Attorney-General of the United States would therefore be appointed by the President of the United States with the advice and consent of the Senate. ${ }^{41}$ It is especially noteworthy that the original proposal, in the case of the Attorney-General of the United States, was to have been

${ }^{38}$ On this question of the different senses of legal propositions and propositions about law more generally, there is no better guide than R Dworkin, 'Legal Theory and the Problem of Sense' in R Gavison (ed) Issues in Contemporary Legal Philosophy: The Influence of H.L.A. Hart (Oxford: Clarendon, 1984).

${ }^{39}$ So far as the prosecutorial powers and discretion of the A-G are concerned, clause 8 of Art 35 Constitution of the Republic of Singapore is wholly unambiguous: 'The Attorney-General shall have power, exercisable at his discretion, to institute, conduct or discontinue any proceedings for any offence.' There is no occasion for doubt; contra the discussion in H Chase and C Ducat Edward S. Corwin's The Constitution and What it Means Today (Princeton NJ: Princeton University Press, 1978) at 189 and 192.

Interestingly, the issue that arose in Singapore concerning the Parliamentary Elections Act (Cap 218) did also concern the A-G's decision not to prosecute. The events here evidently concerned the public interest, and in this case the Government had requested a formal opinion of the A-G and the A-G, in giving that opinion, also consented to its publication (should the Government decide upon such publication which the Government did, evidently).

${ }^{40}$ A Dershowitz 'What is the Attorney-General's Job? December 1996 in A Dershowitz Sexual McCarthyism (New York: Basic Books, 1998) at 74.

${ }^{41} \mathrm{~N}$ Baker Conflicting Loyalties: Law and Politics in the Attorney General's Office, 1789-1990 (Kansas: University Press of Kansas, 1992) at 48. The position in Singapore is, however, governed by clauses 1-3, Art 35 Constitution of the Republic of Singapore. 


\section{THE DENNING LAW JOURNAL}

appointment by the Supreme Court. ${ }^{42}$ This, according to Professor Nancy Baker, would have made the United States Attorney General's office a quasijudicial office but that original proposal was ultimately rejected. ${ }^{43}$ As the method of appointing a United States Attorney-General now stands, instead, the rejection of that original proposal "brought the Attorney-General solidly into the executive branch" in contrast with the position of State AttorneysGeneral. ${ }^{44}$

The Singapore Attorney-General's position is constitutionally different. It has been said in the course of judicial proceedings in Singapore to amount to a quasi-judicial office, and to constitute an "essential pillar of" the Singapore "judicial system". ${ }^{45}$ As with the judiciary, the Attorney-General is granted constitutional protection in respect of security of tenure (until the age of 60) and, therefore, cannot be summarily dismissed. ${ }^{46}$ The exception to that is if the President concurs with the Prime Minister's advice that the Attorney-General has become unable to discharge the functions of his office, or has committed himself to misbehaviour, but even then only when a tribunal consisting of the Chief Justice and two other Supreme Court Justices concurs with the Prime Minister in giving such advice to the President in the first place. ${ }^{47}$ Similarly, the Attorney-General's terms of tenure are constitutionally safeguarded against undue executive intervention. ${ }^{48}$ In this sense, the Attorney-General is independent of the executive.

\footnotetext{
42 Ibid at n 47.

${ }^{43}$ Ibid. Professor Baker cites C Warren 'New Light on the History of the Federal Judiciary Act of 1789’ (1932) 37 Harvard Law Review 49 at 108-109, quoting Senator W Maclay of Pennsylvania.

${ }^{44}$ Probably because certain senators perceived that the A-G of the United States would thereby become a federal creature and this would 'draw by degrees all law business into the Federal Courts'; Baker, ibid, at n 48.

${ }^{45}$ Re Gopalan Nair [1993] 1 SLR 375 (High Court, Singapore), per Chao Hick Tin J, as he then was. See also the short discussion in K Tan and T Li-ann (ed) Tan, Yeo and Lee's Constitutional Law in Malaysia and Singapore (Singapore: Butterworths Asia, $2^{\text {nd }}$ ed, 1997) at 405-406.

${ }^{46}$ Clause 4, Art 35 Constitution of the Republic of Singapore.

${ }^{47}$ Clause 6, Art 35 Constitution of the Republic of Singapore. Clause 6(b) permits an A-G to remain in office after the age of 60 for a period agreed with the Government. This means also that such terms as have been agreed are thereby also granted constitutional protection.

48 Clauses 12 and 13, Art 35 Constitution of the Republic of Singapore.
} 


\section{THE DENNING LAW JOURNAL}

Another sense of the Attorney-General's independence comes to light if we view the matter in functional and pragmatic terms by comparing, say, the existence of the Attorney-General and his staff in Singapore with the position of any other attorney in the Government itself. Government is a whole, it is one, but in everyday terms, it is also a whole of parts, a sum total of many. There are many lawyers employed within Government itself as a sum total of all its parts. Such persons, however, are not all the Government's lawyers, in the strict constitutional sense. The office of the Attorney-General fulfils, therefore, the constitutional role that there should be someone, with the emphasis on the singularity of that source, who holds the principal duty to advise the Government on legal matters. ${ }^{49}$ Anyone armed only with practical common-sense can see the viewpoint that it would not be conducive to good government should the Attorney-General not, and not be able to, stand apart from the various possible and potentially conflicting sources of legal advice which the Government could enjoy. It is an inescapable part of the terms of the Attorney-General's constitutional duty to accomplish a certain detachment, therefore, as he could not fulfil his constitutional duties otherwise. Even clearer, is the fact that the Attorney-General provides an independent source of advice

${ }^{49}$ In Parliament, the Minister of State for Law has referred to the A-G as the Government's “chief legal adviser”; Singapore Parliamentary Debates, Official Record, Vol. 68, 14 January 1998, col 86 (Associate Professor H Kee). The significance of this statement is that it reaffirms in clear and public terms that the A-G leads the giving of legal advice to Government. The point is brought out more clearly if we compare the case of England where it has been said that the Lord Chancellor, as opposed to the A-G there, is the chief legal advisor of the Government; Griffith, see n 37 at 65 (Professor Griffith goes on to say, however, that 'although the more objective and technical advice comes from the Attorney-General'). The question of legal advisory channels was put severely to the test in the spectacular events connected with the Suez Crisis, some of which have only come to light relatively recently with the declassification under the thirty-year rule in England of previously unavailable public documents; see Griffith, ibid, at 65-78; and also Johnman, see n 37. In essence, the British Prime Minister chose the legal advice of the Lord Chancellor and the Master of University College, Oxford as to the legality under international law of a military campaign in the Suez in preference to that of the law officers (the A-G and the Solicitor-General) and the legal advisor to the Foreign and Commonwealth Office. For a contemporary and concise discussion of the positions taken by A-G in England in their public statements, see also C Turpin British Government and the Constitution (London: Butterworths, $4^{\text {th }}$ ed, 1999) at 183184. 


\section{THE DENNING LAW JOURNAL}

to the executive branch. ${ }^{50}$ In this further and important sense then, the Attorney-General is, therefore, not a part of the executive in the strong constitutional sense of the word, meaning that he is not a part of the policymaking apparatus, strictly construed.

Worthington also ignores the fact that when a formal opinion of the Attorney-General is then requested by the Government, the resulting opinion is an opinion given in response to the parameters of the original question. It is simply a constitutional duty of the Attorney-General to offer his legal advice in respect of those questions formally referred to him by the Government. ${ }^{51}$ Again, the question, and it was the pertinent question in respect of the legal issue raised concerning the Parliamentary Elections Act (Cap 218), was whether an offence would be committed under that Act were an unauthorised person to enter and be present in a polling station. Nor is there any other way to put the question, since both in terms of the language of the statute, and the mischief which the statutory provision seeks to address, this was the right question.

It suffices here to say that the first Attorney-General took pains to spell out, in the Crown Suits Ordinance of 1876, the equivalence in terms of duties and

\footnotetext{
${ }^{50}$ The Minister of State has expressed the Government's view thus in the context of Parliamentary debate on the meaning of Art 144 of the Constitution: 'As chief legal adviser, AG is asked, from time to time, to advise the Government on the legality of proposed executive decisions or actions. His role is to give legal advice objectively. In giving such advice, the AG may have to advise the Government on the interpretation of the provisions of a statute. In this case, he had to interpret Article 144 of the Constitution. His advice...represents his own understanding of the law. He does not have to seek a judicial ruling before tendering advice to the Government. Like all legal advisers, AG will assess each case on its own merits. Like all legal advisers, he will not say that there is a strong case if there is really none. After all, he has to stand by his opinion to the Cabinet, and if it becomes public as it has now, then to Singaporeans and indeed to others in the world who may care to read it, examine it...': Singapore Parliamentary Debates, Official Record, Vol 68, 14 January 1998, col 86 (Associate Professor Ho Peng Kee). In the United States, the issue arose most recently in the constitutional imbroglio pertaining to the investigation of President Clinton by Independent Counsel; see Dershowitz, see n 40.

${ }^{51}$ Clause 7 Art 35 Constitution of the Republic of Singapore: 'It shall be the duty of the Attorney-General to advise the Government upon such legal matters and to perform such other duties of a legal character, as may from time to time be referred or assigned to him by the President or the Cabinet and to discharge the functions conferred on him by or under this Constitution or any other written law.'
} 
functions of the Attorney-General in England at the time, and the AttorneyGeneral of what was then the Straits Settlements. This is discussed by another former Attorney-General, Mr. Tan Boon Teik, in an article published in 1988 in the Malayan Law Journal. ${ }^{52}$ The article, however, notes that what makes the two different, is that the Attorney-General in England is a political appointee, but the Attorney-General of Singapore is not. Here too we should distinguish between the different senses of the notion of "political appointment". Whereas a public appointment would necessarily involve a process which is "political" in a weak sense, this does not always mean that the appointment is a "political appointment” in the stronger sense.

\section{THE “HEGEMONY” ARGUMENT}

"I am saying that the real world depends upon our values (and, again, vice versa)" 53

Worthington's principal criticism has to do with what he sees as the pervasive influence, indeed hegemony, of a Singapore power elite. There is nothing new about the "hegemony argument" itself, if I might call it thus, and it is, in fact, a routine feature of recent Singapore constitutional writing. ${ }^{54}$ Nor is there any magic involved in talking in terms of "hegemony", a word originally defined, albeit in a bit of a mouthful, in terms of "the spontaneous consent given by the great mass of the population to the general direction imposed on social life by the dominant fundamental group (i.e. the ruling class)". It is, after all, simply an old classroom device of the philosophy teacher dressed up in new clothes with the popularisation of the Prison Notebooks of the Italian communist, Antonio Gramsci, whose words I have just quoted, ${ }^{55}$ and which have so captured the imagination of the European literati left. According to this philosophical device, the students are to imagine that they are brains in vats that

52 T Teik 'The Attorney-General' [1988] 2 Malayan Law Journal l viii.

${ }^{53} \mathrm{H}$ Putnam Reason, Truth and History (Cambridge, Cambridge University Press, 1981) at 135.

54 See Thio see $\mathrm{n}$ 8. See also Chen see $\mathrm{n} 8$ for the origins of this critique in the wider Singapore social science literature and which also appears in O Hui, T Kiong and T Ser (ed) Understanding Singapore Society (Singapore: Times Academic Press, 1997) as does Professor C Chee's ground-breaking 1975 essay.

${ }^{55}$ A Gramsci Selections from the Prison Notebooks (London: Lawrence and Wishant, 1971) at 12 . 


\section{THE DENNING LAW JOURNAL}

are only deliberately given the impression by alien beings that they have a corporeal existence in a physical world. Worthington forgets, however, the original lesson contained in this device, which is that one of these philosophy students, as it will be noticed at once, would have to be something other than a brain in a vat to know better, and so the point is to show that the sort of "higher political truth" the notion of hegemony appeals to is, really, a sort of logical fraud. ${ }^{56}$ Hegemony as a left-tool of criticism presupposes, likewise, that the participants in societal discourse and inter-course do not but should know better. Yet in this, the tool assumes a transcendental viewpoint that does not exist, or cannot be established without itself requiring a normative judgment imposed from the outside. It is this value imposition from outwith that amounts to a metaphysical fraud. ${ }^{57}$

\section{PUTTING THE HEGEMONY ARGUMENT TO SOCIOLOGICAL (MIS)USE}

Worthington's hegemony argument forms the principal basis for a number of wider observations about Singapore law. It accounts for a second type of methodological failure, in addition to a first kind which I discussed in Part IV

\footnotetext{
${ }^{56}$ See Putnam, see n 54, at 1-21 and 130-135. Putnam goes on to show that the point in the example holds even where a vast number of persons hold the view that the example actually represents reality. As he puts it: '....imagine that this crazy (and I would claim, incoherent) theory, the theory that we were all brains in a vat, is held not by an isolated lunatic, but by virtually all the people in a large country, say Australia. Imagine that in Australia only a small minority of people believe what we do and the great majority believe that we are Brains in a Vat' (Putnam, ibid, at 131). Then Professor Putnam poses the problem here 'The first thing I want to observe about the hypothetical Australians is that their world view is crazy...I think we would regard a community of human beings who held so insane a world view with great sadness. The Australians would be regarded as crazy in the sense of having sick minds; and the characterization of their minds as sick is an ethical one, or verges on the ethical. But how other than by calling them names, could one argue with the Australians?' (Putnam, ibid at 132). Putnam argues that we would ultimately be arguing about what our values are (Putnam, ibid at 135).

57 The Singapore press, in its enthusiastic review of Dr Worthington's book, took instead a slightly different tack: 'His analysis contributes a critical voice to the perennial debate on whether the Singapore system, while highly effective in some ways, is too concentrated in the hands of a small, self-perpetuating elite' says the Straits Times, 26 April 2003.
} 


\section{THE DENNING LAW JOURNAL}

above. That first failure is conceptual. Its cause lies in ignoring formal-legal explanations of the meaning of certain social facts. These social facts, I have argued, cannot be explained in isolation from the legal concepts that infuse and circumscribe their social meaning. The constitutional position of the AttorneyGeneral cannot, for example, be described, or criticised, without accounting for what the Constitution actually says about the Attorney-General's position because the Attorney-General is bound by the Constitution. The second form of failure is unlike the first. It is, instead, an empirical failure. The failure involves getting social facts plain wrong because the ordinary (as opposed to legal) social meaning of such facts is misunderstood.

Some of Worthington's conclusions, particularly those that have to do with the relationship between the core executive and the legislature, fail in precisely this way. For example, a previous era in which law school teachers were called upon to fill administrative, and also political, positions has led some of Singapore's most able legal theorists into public service on secondment. That they would retain their Faculty positions is something that is in the very nature of a secondment, but this does not mean that they thereby do so in their administrative or political capacity. Worthington, however, seems to go down the road of saying that if $\mathrm{X}$ belongs to groups $\mathrm{A}$ and $\mathrm{B}$, and $\mathrm{Y}$ belongs to groups $\mathrm{B}$ and $\mathrm{C}$, then $\mathrm{X}$ also belongs to group $\mathrm{C}$, or $\mathrm{Y}$ also belongs to Group $\mathrm{A}$, or that Groups A and C must of necessity have something to do with each other, or some such thing. These suggestions are simply illogical on these terms, but if the point aims to go beyond logic, we should at least require some evidence of why someone should think that academic freedom has been compromised.

In the same vein, the reason the Singapore Law Review is "overseen by a board which is controlled by the Law Faculty of the NUS and the judiciary" (notice how the point is put) would hardly raise eyebrows anywhere else, ${ }^{58}$ for the very simple reason that it is a student law review. Law journals generally do have judges on their advisory boards, but, again, this would hardly raise an eyebrow anywhere else, nor should it. Likewise, the previous dean of this law school has been a leading Government backbencher for years, so one is left wondering about what Worthington had in mind with his revelation in a footnote in the book that the Honourable (PAP) Member for Sembawang GRC is "probably a PAP cadre". 59

\footnotetext{
${ }^{58}$ See $\mathrm{n} 31$ at 279.

${ }^{59}$ Ibid. In any event, I had just about given up on Dr Worthington's study by the time I came upon his persistent confusion of my Faculty colleague, Professor V Winslow, for
} 
Something is therefore not quite right here in the sense that all these points, which really are intended to say something real, important and interesting about the politics of legal knowledge in Singapore, even something profound about how Singapore law chooses to view itself, are somehow reduced, by way of that old chestnut of Gramsci's to speculation and titillation instead.

\section{FORM AND FUNCTION IN POST-COLONIAL ANTHROPOLOGY}

"...those who refuse to accept the rules, out of weakness or crudeness are excluded" 60

There is a deeper explanation of where Worthington's social-scientific methodology goes astray and it contains wider lessons for comparative constitutional discourse. The legal-conceptual and empirical failures I have described in Parts IV and VI lie in the fact that the methodological insights of post-colonial legal anthropology have somehow been ignored. It is simply insufficient to make up theories whose terms and categories are defined in such a way that they cannot be falsified by the facts on the ground, viewed from an indigenous perspective. The late Professor Antony Allott of the School of Oriental and African Studies taught an entire generation of field anthropologists working in the post-colonial era that rigorous empirical work is also about how certain governing ideas perform certain functions, and not what form these governing ideas take (or, fail to take, according to Worthington's armchair descriptive sociology. ${ }^{61}$ Equally, and with respect to so much critical Singapore

my colleague's late father in several repetitive and pointless footnotes before he then speculates aloud as to why his findings make no sense here, see n 142 at 307 . Thankfully, this line of enquiry was omitted in the article in the Journal of Law and Society.

60 J Lyotard The Postmodern Condition: A Report on Knowledge (Manchester: Manchester University Press, 1984) at 28 citing V Goldschmidt Les Dialogues de Platon (Paris: Presses Universitaires de France, 1947). The discussion in Lyotard is of Plato's Dialogues and of the claims to truth therein, whereas, alas, the Platonic Dialogues have been portrayed to the world beforehand in the manner of a scientific discussion.

${ }^{61}$ The late Professor Allott's criticisms of Professor Hart's descriptive sociology are highly instructive on this point; see A Allott, The Limits of Law (London: Butterworths, 1980), at 51-54. Simply put, if you take a whole bunch of abstract legal concepts and 


\section{THE DENNING LAW JOURNAL}

scholarship, ${ }^{62}$ the notion of hegemony is simply not well suited towards an analysis of Singapore's legal institutions. The need to locate the processes of power in large post-industrialised societies may well require supreme abstractions so as to accomplish the task, but where this may be warranted where the society is large, highly differentiated and complex, in the case of a society the size of Singapore's such high-powered intellectual gadgets smack, instead, of a kind of methodological over-reaction at best. ${ }^{63}$

Allott's point was that simply because a particular (tribal) culture may not evince the same sorts of legal institutions as those found in some modern industrialised societies does not mean that the former is lawless or primitive. In any case, you don't take the experiences of one culture and the legal institutions thrown up by that experience and translocate these lock, stock and barrel so as to hold another culture to judgment. ${ }^{64}$ I need only quote Denning on this in Nyali Ltd v Attorney-General, concerning the then British East African territory of Kenya: ${ }^{65}$

"The next proviso provides, however, that the common law is to apply 'subject to such qualifications as local circumstances render necessary'. This wise provision should I think, be liberally construed. It is a recognition that the common law cannot be applied in a foreign land without considerable qualification.”

Even worse are double-standards. For example, it is the usual international law practice today to seek the opinion of foreign counsel abroad when a point of foreign law arises. Worthington dismisses instead the idea that Singapore

seek to translate them into various other languages, it would not take you very long to find out that there will be many of these abstract ideas conceived in their original language that would fail to convey their point at all in another language. This was coming from someone with forty years of field anthropological experience.

${ }^{62}$ In Singapore public law scholarship, see Thio see $\mathrm{n} 8$, where the concept is also put to use.

${ }^{63} \mathrm{Dr}$ Worthington himself acknowledges that the model he adopts is not that of Dunleavy's and Rhodes' "large, modern nation state", see n 19. See further P Dunleavy and R Rhodes ‘Core Executive Studies in Britain' (1990) 68 Public Administration 3.

${ }^{64}$ Allott see $\mathrm{n}$ 61, especially at 112-113, for the expression of this sentiment.

${ }^{65}$ [1956] 1 QB 1 at 16 per Denning LJ. See Allott see n 61 at 109 et seq for a discussion of some of the problems posed by the translocation of laws. 


\section{THE DENNING LAW JOURNAL}

lawyers are best qualified to interpret Singapore law. He says that such a notion is "intellectually arrogant" and demonstrates "a lack of genuine international experience". ${ }^{66}$ I only mention this because it is a criticism that is widely heard elsewhere amongst those who consider the Singapore legal system defective in a fundamental sense.

There are other examples of how different systems will adopt different means to address common issues. Singapore has chosen to try and have a highly skilled legal service which, being a scarce resource, may also be drawn upon to operate a subordinate judiciary. Yet this does not mean that what is sought is simply "efficiency". It would have (and is intended to have) an obvious impact on the quality of the delivery of justice. That such a system would thereby produce murder convictions sooner rather than later, however, is a logical consequence of a criminal justice system that supports the death penalty still. Be that so, it does not make the criminal justice system an "efficient state killing machine," ${ }^{67}$ unless the debate is really about the death

\footnotetext{
${ }^{66}$ See n 122 at 305

${ }^{67}$ See $\mathrm{n}$ 114. As for the subordinate courts, Dr Worthington is again mistaken in
} thinking that subordinate court judges are answerable (only) to the A-G and that the A$G$ is a member of the Government of the day. I have already discussed the latter misconception. As for the former, subordinate court judges are accountable to the Legal Service Commission, which exists under Art 111 Constitution of the Republic of Singapore. In essence, the independence of the subordinate judiciary "piggy-backs" on the constitutionally safeguarded position of the members of the Legal Service Commission. Theirs is thereby a "derivative independence" in that sense. The Chief Justice sits as President of the Commission. The other members of the Commission are the A-G the Chairman of the Public Service Commission (who is also the Chairman of the Commission), another Supreme Court Justice appointed by the Chief Justice and up to two other members of the Public Service Commission appointed by the Chairman of the Public Service Commission, in that order. What is important is that they all have their independence safeguarded by provisions in the Constitution, and in the case of the justices of the Supreme Court and the A-G, there is a high degree of formal independence, more so than in the case of the Chairman and two members of the Public Service Commission; see Hor see n 34 at 505. The key issue as Hor puts it is: 'It is not at all clear how much further institutional protection of independence can go. If indeed the Commission transferred the judge out of the improper motive of appeasing the executive, what was problematic was not so much independence of the subordinate judiciary from the executive but independence from the superior judiciary and the Attorney-General', however 'If the subordinate judiciary is not to be subject to the superior judiciary, then it is not obvious to whom it should be subject to.' My 


\section{THE DENNING LAW JOURNAL}

penalty (which Singapore continues to impose), but it is not. These aspects of the legal system and the development of efficacious alternative means for the resolution of commercial and financial disputes is, at the end of it all, what studies like the World Competitiveness Report are really about.

I do not mean to deny the role of an over-arching, comprehensive critique of Singapore's "living" constitution, but only to argue that a sound theory about the Singapore Constitution must, first, precede such a critique. Such a theory may yet find expression in the language of contemporary Anglo-American jurisprudential debate, even if there are articles of faith dear to the AngloAmerican tradition which may have been modified or even lost in the course of the development of an indigenous Singapore system. The former Dean of the Yale Law School has in recent years been arguing for something that does, for example, have some relevance towards an understanding of what is going on here in Singapore. According to Dean Kronman, legal training and practice consist of the cultivation of a "lawyer-statesman ideal". He defines this as the need to view legal education and practice as a way of cultivating practical wisdom in handling the tangled skein of human affairs, unlike the current dominant viewpoint that the "correct" legal theory and legal-institutional architecture and institutions would both be necessary and adequate for the purposes of modern industrialised societies, an assumption shared by $\mathrm{Dr}$ Worthington.

While Dean Kronman laments the erosion of this ideal today, not least in the way the law is taught in American law schools, that ideal (perhaps ironically, in more ways than one) continues to claim its rightful place in the classroom and courtrooms in Singapore. Neither the law and economics movement, nor any other law and social science or law and policy mindset may be said to prevail in our schools, courtrooms or law firms. Most lawyers here, and I would have thought elsewhere too, accept that the plainest constitutional terms can be made to mean whatever is sought to be attributed to them in light of particular circumstances and opportunities, with a little legal skill and firm possession of decision-making power. In legal practice, this may best be exemplified in countries where difficulty in getting the constitution changed has forced case-law interpretation to depart radically from the ordinary meaning of

discussion of judicial independence will, therefore, be confined to the superior judiciary. 


\section{THE DENNING LAW JOURNAL}

the plain terms of the constitutional text. ${ }^{68}$ We also have a particularly acute appreciation of the issue as Anglo-American jurisprudence begins to grow out of the dizzy years of critical legal scholarship. The Singapore lawyer-statesman ideal, if I might term it thus, recognises, however, this singular practical quality of judicial power; what Professor Dworkin has termed the "force of law" itself, as distinguished from theories of its moral-political justification. Dworkin thinks the aspect of moral-political justification is what jurisprudence is about, and that judging is also a way of "doing jurisprudence", in the same way that jurisprudence, properly construed, must thereby be interested in the production of adjudicatory theories. ${ }^{69}$ In the case of Singapore, if we take judicial appointment as a test, the criteria for that are no different from those of any key public office, where practical judgment (what Kronman calls "character") is seen to matter just as much, if not much more, in public decision-making than getting "the right" abstract theories and ideals going about the law and legalinstitutional architecture. ${ }^{70}$ Concomitantly, the dominant thinking here is less concerned with adjudicative theories, deconstructive theories, and prescriptive theories of the law and legal-institutions. It is against this precise background and context that scarce judicial talent is seen to require those past retirement age to continue to remain on the bench. Experience has shown, even in the very

${ }^{68}$ There are many theories that seek to capture what legal interpretation must mean in light of this, where debate centres around those who propound ever new and more innovative arguments for favouring adherence to some real or reconstructed original intent of the drafters to those who argue for judicial activism and those who seek only to describe and explain both what has gone on before and how judges should continue to proceed in terms of some overarching theory of the adjudicative function. The most popularly known example of such theories today is probably Professor R Dworkin's; see his Law's Empire (Cambridge Mass: Belknap Press, 1986).

${ }^{69}$ Ibid at 108 et seq. He says at 110, for example, that: 'A full political theory of law, then, includes at least two main parts: it speaks both to the grounds of law circumstances in which particular propositions of law should be taken to be sound or true - and to the force of law - the relative power of any true proposition of law to justify coercion in different sorts of exceptional circumstance. These two parts must be mutually supportive. The attitude a full theory takes up on the question how far law is commanding, and when it may or should be set aside, must match the general justification it offers for law's coercive mandate, which in turn is drawn from its views about the controversial grounds of law.'

${ }^{70}$ For a first-hand account of the appointment of the present Honourable Chief Justice, where both dimensions are seen to be present see L Yew From Third World to First, the Singapore Story: 1965-1990 (New York: Harper Collins, 2000) at 216-220. 
few years between the completion of Dr Worthington's project and the date of publication of his book last year, that there is, on the contrary, a keenness, typical of Singapore's policy thinking, for renewal. In this way, critics like Dr Worthington and the decision-makers appear of one mind. At present, only two judges sit on Singapore's Court of Appeal as of right, the Chief Justice and Judge of Appeal, Chao Hick Tin. The third post remains vacant with the departure, since his time of writing of Judges of Appeal Karthigesu and, more recently, L P Thean. ${ }^{71}$ It suffices to say that when the highest appellate body of a nation comprises simply three Justices, the third-seat is the equivalent of three United States Supreme Court Justices.

\section{CONSTITUTIONS, GOVERNMENTS AND COURTS}

None of what I have had to say in this defence of aspects of the Singapore Constitution should suggest that maintaining a separation of powers in the classic sense of having checks and balances is not considered important at the highest levels of official thinking. ${ }^{72}$ True, law-making is seen here largely as a question of legal policy and this explains the extent in Singapore of legislative intervention. Having said that, Singapore's experience is not unusual amongst modern industrialised societies (notwithstanding that nation-building in Singapore has required active policy stewardship). Consider, for example, the intrinsic merit in having certainty in sentencing policy and practice. ${ }^{73} \mathrm{Dr}$

\footnotetext{
${ }^{71}$ The Senior Minister's account, describing the initial reluctance of the presently incumbent Chief Justice, reminds me of the description in Stubbs' magisterial work of a certain T Gamel who would not deign to attend Parliament in 'an age when the office of representative was regarded rather as a burden than as a privilege' and was reported, in what I take to be lucid Norman French, would: 'ne se deygne venir pur riens que nous savons fair': W Stubbs Constitutional History of England in its Origin and Development Volume III (Oxford: Clarendon, 1878) n 1 at 421. Worthington's general portrayal of Singapore judges being constrained by considerations of tenure would appear just as odd to twenty-first century Singapore eyes.

${ }^{72}$ For which, see the response in Parliament of Professor S Jayakumar, the Minister for Law to the speech of Nominated Member, Mr Tay on the issue: Parliamentary Debates, Official Record, Vol 68, 14 January 1998, cols 90 - 94 (Associate Professor S Tay) and 96 (Professor S Jayakumar).

${ }^{73}$ See $\mathrm{n}$ 120. I have already discussed the error he commits in respect of the law relating to judicial review in Singapore. As for the fact that we now live in an age of statutes, this is hardly new across the length and breadth of the common law, or unique
} 


\section{THE DENNING LAW JOURNAL}

Worthington says that, in terms of the Singapore criminal justice system, this means simply that "the executive does the sentencing via legislation". His statement is bizarre and a good illustration is a recent high-profile case which the press observed had put the prosecution on the side of the defence. The Attorney-General, in the name of the public interest, had referred the sentencing decision of the Chief Justice to the Court of Appeal, contending that the sentence there was more severe than the law should allow, and that the Chief Justice had got the law wrong. An unanimous Court of Appeal (comprising Justice of Appeal Chao Hick Tin, and Justices M.P.H. Rubin and Tan Lee Meng) agreed and reversed the Chief Justice's decision. ${ }^{74}$ That reversal, in my view, does not have the look or appearance of a society without checks and balances.

But what should Singapore have for a separation of powers? Here, Dr Worthington's criticisms again serve as a useful foil. Singapore is in the bizarre situation, in common with various other former British colonies, of having a written constitution which a British judge would be challenged to apply, in my view, particularly if such application is to be performed from the great heights of English law. It must be doubted too how such cabinet government and a Parliamentary majority in the Westminster senses should accommodate a Constitution replete with a supremacy clause (Article 4), not to mention two centuries of United States Supreme Court jurisprudence. Take the term "judicial review". What a splendid term, but what does it mean in Singapore?

For Worthington, he means to refer either to the English or the American usages of the term. Yet he fails to recognise that these are two very different senses of "judicial review". He fails to recognise in fact the principal constitutional difference between Westminster-style government and something more akin to the United States model. So he says that (the English version of) judicial review in Singapore has been shackled by legislation.

In reality, however, the superior courts in Singapore have not hesitated in claiming the power to strike down legislation (even those that seek to shackle the courts' ability to do so) should such legislation offend the Constitution in the eyes of the courts. Article 4 of the Singapore Constitution has been invoked to supply this judicial power. Such a thing would be unthinkable in England at

to Singapore; see G Calabresi A Common Law for the Age of Statutes (Cambridge Mass: Harvard University Press, 1982).

${ }^{74}$ Straits Times, May 202003 and August 23 2003. See s 60 Supreme Court of Judicature Act (Cap 322). 


\section{THE DENNING LAW JOURNAL}

common-law, ${ }^{75}$ whereas in the history of the United States Constitution, as everyone well-knows, the power of judicial review originated there, instead, in the form of a brilliant but naked usurpation of power by Chief Justice John Marshall's Supreme Court. ${ }^{76}$ When Dr Worthington talks then about the

${ }^{75}$ See now, for the position in English law resulting from the Factortame litigation; $R v$ Secretary of State for Transport ex parte Factortame Ltd [1989] 2 CMLR 353 (CA); $R$ $v$ Secretary of State for Transport ex parte Factortame Ltd [1990] 2 AC 85 (HL); Rv Secretary of State for Transport ex parte Factortame Ltd (No 2) [1991] AC 603 (HL); Case C-221/89 R v Secretary of State for Transport, ex parte Facortame ( No 3) [1992] QB 680 (HC); $R v$ Secretary of State for Transport, ex parte Factortame Ltd (No 5) [1998] COD 381 the Merchant Shipping (Registration, Etc) Act 1993 s 3; the Merchant Shipping (Registration of Ships) Regulations 1993, SI 1993 No 3138. The game was up by the time of Factortame (No 2). See further $R v$ Secretary of State for Employment, ex parte Equal Opportunities Commission [1995] 1 AC 1.

${ }^{76}$ The events here bear a summary description. At the turn of the nineteenth century, every Federalist judge had become implicated in the prosecution (history says 'persecution') of 'Jacobin' Republicans under the Sedition Act enacted by the 'Tory' Federalists led by John Adams. The Federalists thereafter lost control of Congress, and in the case of $\mathrm{J}$ Adams the Presidency to $\mathrm{T}$ Jefferson. A lame duck Congress and President succeeded, however, in packing the courts at federal district and circuit levels with Federalist nominees as well as a disproportionate number of newly created Justices of the Peace for the District of Columbia. The Federalists meant to govern the country through the courts instead. On the night before the handover, J Marshall, then J Adams' Secretary of State, having signed and sealed the letters of appointment for the "midnight judges" neglected however to secure their delivery, and thus they fell short of having legal effect. The new Secretary of State (J Madison) refused to complete the appointments by delivering them. The matter then came before the Supreme Court by way of an application for mandamus by one of the four "midnight judges" (Marbury) who had brought legal action so as to compel Madison to complete the task of appointment. In this way, J Marshall himself, who had also been confirmed as Chief Justice of the Supreme Court before the handover, presided over the Supreme Court hearing to remedy his own administrative oversight, and found for W Marbury. Marshall was then faced with the question of the remedy sought by Marbury. The Supreme Court unfortunately lacked the jurisdiction to order the relief sought under Section III of the First Congress' Judiciary Act of 1789, for its original jurisdiction was limited to cases in which a state is party and cases involving ambassadors, other public ministers, and foreign consuls. Marshall could have stopped there and simply let Marbury's lawyer take the matter to the right court, but he did not and, instead, uttered those famous words "If an act of the legislature, repugnant to the Constitution, is void, does it, notwithstanding its invalidity, bind the courts, and oblige them to give it 


\section{THE DENNING LAW JOURNAL}

separation of powers, the supposedly "anti-judicial” (and thereby supposedly "anti-rule of law") attitude of the Singapore legislature, and the supposedly shackled Singapore courts, he ends up in total confusion for he slips and sways between two very different senses of the term "judicial review", divided by the vast Atlantic. ${ }^{77}$ Either that or he is advocating, instead, that the Singapore

effect?" His answer: "It is emphatically the province and duty of the judicial department to say what the law is." In itself, this was hardly startling as a matter of law, but for its constitutional effect in the political circumstances of the case. Thus was the judicial power secured both to nullify Congress' actions, and the Judiciary Act was indeed Congress' creature, and to ensure that the executive could not evade judicial orders: P Irons, A People's History of the Supreme Court (New York: Viking Penguin, 1999) at 96-107.

${ }^{77}$ As Dicey put it succinctly: 'The American judge must in giving judgment obey the terms of the Constitution, just as his English brother must in giving judgment obey every Act of Parliament bearing on the case': Dicey, see n 13 at 88. Similarly, he confuses two different kinds of apparent limitations to the power of judicial review in English law alone. Legislative provisions containing clauses that purport to make the Minister's decision "final" are more apparent in their legal effect than real, although some other clauses achieve just that. The two categories of legislation which I have just described differ vastly. Examples of the first may be found, for example, in the Newspaper and Printing Presses Act (Cap 206), the Undesirable Publications Act (Cap 338), the Films Act (Cap 107), the Public Entertainments Act (Cap 257), the Miscellaneous Offences (Public Order and Nuisance) Act (Cap 184), the Public Order (Preservation) Act (Cap 258), and the Societies Act (Cap 311). However, they are, in fact, legally subject to the usual principles of judicial review. Depending on the proper construction of their terms by the courts, the Minister's decision would hold (or the President's decision, where appeal to a final decision of the President is provided, such as in the case of the Newspaper and Printing Presses Act in respect of the licensing of printing presses) only if the discretion exercised therein were in keeping with certain requirements. These include the basic requirements of procedural fairness, the need for such exercise of executive discretion to have been in good faith and to fall within the terms prescribed under the particular legislation, and also the need for such an exercise of Ministerial discretion to meet any other statutory requirement to be found in a particular Act. Aside from the other ancient prerogative writs and the legal fiction of nullity where an executive decision is found to have been ultra vires, an order of certiorari would also be available to quash the decision reached. In this respect, the law, as stated by the English Court of Appeal in $R v$ Medical Appeal Tribunal ex parte Gilmore [1957] 1 QB 575 (CA) would still apply in Singapore under the Young $v$ Bristol Aeroplane rule, subject to departure under the Practice Statement of 1994, see n 18 above. Gilmore is a good example since the legislative drafting formula there was 
contained in a clause stating, precisely, that 'any such order or decision shall be final.' Dr Worthington is, therefore, not only wrong with respect to this general class of Acts, but also in respect of the Passports Act (Cap 220), for example, see n 92 at 302. Subsidiary legislation exists under the Passports Act in the form of the Passports Regulations. Paragraph 15(1)(a) of the Passports Regulations states that the Minister's decision "shall be final." Moreover, and this is what makes it a second separate class from the first, that clause is contained in subordinate not primary legislation and English lawyers know the legal difference. In any case, the provisions in these two classes of (primary and secondary) legislation employing clauses which purport to make executive decision final differ, again, from a third class of provisions which in Singapore would normally pertain to matters of national security only, although even here, should national security be asserted by the Minister, its characterisation as such may be challenged still in Singapore on grounds of legal irrationality: Chan Hiang Leng Colin v Minister for Information and the Arts [1996] 1 SLR 609, at 621G-I - 622A. Arguably then, judicial review is only properly excluded as a matter of Singapore law in the case of the employment of very clear ouster clauses, such as that to be found in s $8 \mathrm{~B}(2)$ of the Internal Security Act (Cap 143). Section 8B(2) states that: "There shall be no judicial review in any court of any act done or decision made by the President or the Minister under the provisions of this Act save in regard to any question relating to compliance with any procedural requirement of this Act governing such act or decision.' What the draftsman must have had in mind here was Lord Reid's words that 'It is a well established principle that a provision ousting the ordinary jurisdiction of the court must be construed strictly, meaning, I think that if such a provision is reasonably capable of bearing two meanings the meaning should be taken which preserves the ordinary jurisdiction of the courts'; Anisminic v Foreign Compensation Commission [1969] 2 AC 147 (HL) per Lord Reid. The law pertaining to judicial review of administrative action is exceptional for the purposes of the Internal Security Act. It is a codification of the common-law as at 13 July 1971 pursuant to the combined legal and constitutional effect of the Constitution of the Republic of Singapore (Amendment) Act, No 1 of 1989 and the Internal Security (Amendment) Act, No 2 of 1989. The common law at the time was expressed in Lee Mau Seng v Minister of Home Affairs [1971] 2 MLJ 137. Nonetheless Anisminic, howsoever construed, would still apply under this specialised rule. Technically the draftsman's intent behind the drafting language of s 8(B)(2) may thus be attributed to a professional excess of legal caution since the High Court in Lee Mau Seng had upheld the clause purporting to make executive decision final ('if the President is satisfied'). While comprehensive examination of this point of law is beyond the scope of this review, see also South East Asia Firebricks Sdn Bhd v Non-Metallic Mineral Products Manufacturing Employees Union \& Ors [1980] 2 MLJ 165 (Privy Council), I mention these cases to illustrate an important comparison. Namely that clauses similar to that in s 8B(2) of Singapore's Internal Security Act (Cap 143) proliferated in England in response to Anisminic; see, 


\section{THE DENNING LAW JOURNAL}

courts should have been striking down legislation left-right-and-centre all along, but he does not tell us why this should be so.

He is aware, for example, that the Court of Appeal in Bridges has said that, in Singapore, the courts shall decide what an official secret is, not the executive. Worthington neglects the constitutional significance of this. ${ }^{78}$ The case is not simply about official secrets. Instead of invoking the Constitution (which could have precipitated a constitutional incident), the Singapore courts confined themselves to the strict construction of the statute. ${ }^{79}$ Despite this, lawyers know that, in the ultimate constitutional analysis, what the Court of Appeal in Singapore has had to say about this is also backed, if need be, by the constitutional powers granted to the court, amongst other things to protect the freedom of speech and expression in Singapore. Constitutional scholars nonetheless admit, as Dean Guido Calabresi had put it once in his Oliver Wendell Holmes Lectures in 1977, ${ }^{80}$ that: "Constitutional adjudication and use of the passive virtues, though not unusual reactions to anachronistic laws, are not the most common judicial responses. The traditional judicial weapon in dealing with statutes has always been interpretation of what the written law means.”

Had the courts been challenged by the executive, Singapore could have been required to have its own Marbury $v$ Madison. ${ }^{81}$ What is striking is that this affair occurred with hardly a murmur in the legal literature, and without any great fanfare. Balfour would have been elated at our Englishry at a moment in Singapore's constitutional history where it counted most. ${ }^{82}$ But you could say

for example, s 7 of the British Communications Act 1985 and s 44 of the British Nationality Act 1981. For a further illustration of some of the legal distinctions drawn in this footnote, however, see C Lim 'Executive Lawmaking in Compliance of International Treaty [2002] Singapore Journal of Legal Studies 73.

${ }^{78}$ Worthing, $n 1$ see pp 111, 136, 155 and 164 . He is simply wrong in saying that the Chief Justice presided over the Court of Appeal in this case. The Chief Justice was sitting in the High Court and the matter was brought before the Court of Appeal by way of a criminal reference by the A-G.

${ }^{79}$ Bridges Christopher v Public Prosecutor [1997] 1 SLR 406,per Yong Pung How CJ; and the decision of the Court of Appeal arising from the criminal reference brought by the A-G under s 60 of the Supreme Court of Judicature Act (Cap 332) in Public Prosecutor v Bridges Christopher [1998] 1 SLR 162 per Karthigesu JA.

${ }^{80}$ Calabresi see $\mathrm{n} 73$ at 31 et seq.

${ }^{81} 5$ US (I Cranch) 137 (1803); see see $n 76$.

${ }^{82}$ Whose Preface to W Bagehot's The English Constitution (Oxford: Oxford University Press, 1949), at xxiv Dr Worthington cites; n 46 at 328. 


\section{THE DENNING LAW JOURNAL}

that the Singapore Court of Appeal heeded both Justice Jackson of the United States, ${ }^{83}$ and Bagehot's warning, spoken against glib comparisons of Westminster with the American model. ${ }^{84}$

Worthington also ignores the fact that in that same year, in 1998, the High Court in Singapore went even further in Eddie Taw. Instead of simply construing the relevant statute narrowly, it went forth, as I mentioned earlier, to strike down a legislative provision for being contrary to Article 12 (the equal protection clause in the Constitution). ${ }^{85}$ The Court of Appeal disagreed with the High Court for reasons related to the conduct of Singapore's foreign policy and upheld the statute in question. ${ }^{86}$ The Court of Appeal read the Constitution in the light of the legislative purpose doctrine instead, and found the particular statutory provision to have been consistent with Article 12. According to the Chief Justice, the mischief sought to be addressed by Parliament in extending Singapore's criminal jurisdiction to the conduct of permanent residents and citizens abroad, but not to do so in respect of foreigners, was intelligible nonetheless to an ordinary and reasonable citizen (whose interest it is that would be affected by the differentiation drawn). ${ }^{87}$ In contrast, most American judges would I think be surprised at the suggestion of such a matter as that in

83 'We are not final because we are infallible, but we are infallible only because we are final' in Brown v Allen 344 US 443, 540 (1953).

84 'The more we study the nature of Cabinet Government, the more we shall shrink from exposing at a vital instant its delicate machinery to a blow from a casual, incompetent, and perhaps semi-insane outsider.' My reference is to the American publication of the second edition of 1872: W Bagehot The English Constitution (New York: Dolphin Books, Doubleday \& Co, year of publication unknown) at 249-250, 264.

${ }^{85}$ Taw Cheng Kong v Public Prosecutor [1998] 1 SLR 943 (High Court of Singapore), per Karthigesu JA. Art 4 Constitution of the Republic of Singapore was construed in light of this as the basis for the judicial power to strike down offending legislation: 'This Constitution is the supreme law of the Republic of Singapore and any law enacted by the Legislature after the commencement of this Constitution which is inconsistent with this Constitution shall, to the extent of the inconsistency, be void.' See also the Parliamentary speech of Nominated Member, Mr S Tay, Parliamentary Debates, Official Record, Vol 68, 14 January 1998, cols 90 - 94 (Associate Professor S Tay).

${ }^{86}$ Public Prosecutor $v$ Taw Cheng Kong [1998] 2 SLR 410, at 434E per Yong Pung How CJ.

${ }^{87}$ See C Lim 'Singapore Crimes Abroad' [2001] Singapore Journal of Legal Studies 494 at 529-533; J Ely Democracy and Distrust - A Theory of Judicial Review (Cambridge Mass: Harvard University Press, 1980) at 251; Note 'Legislative Purpose, Rationality and Equal Protection’ (1972) 82 Yale Law Journal 13. 


\section{THE DENNING LAW JOURNAL}

the Eddie Taw case having come this far, instead of steering clear away from foreign policy questions. ${ }^{88}$ In England, executive certification would, more likely than not, have been the end of the matter. ${ }^{89}$ In Australia too, the famous decision of Mabo (No. 2) had proceeded along the same lines. There is a close resemblance with the reasoning of Justice Brennan, with whom Chief Justice Mason, and Justices McHugh, Deane, Gaudron, Dawson and Toohey all concurred. According to this line of reasoning, the original acquisition of Australian territorial sovereignty is invested with the significance of an Act of State, prohibiting therefore the issue of native land from falling within the jurisdiction of the Australian courts. ${ }^{90}$ In nearby Singapore, the Chief Justice, who wrote the opinion of the court in the Eddie Taw case, agreed with the submission of the Attorney-General, and considered the basis of Singapore's extraterritorial penal jurisdiction to lie beyond the Constitution itself, inhering instead in the sovereignty of the Republic. ${ }^{91}$ This point was upheld, again, in recent months by the Australian Federal Court in the Petrotimor Case, which is even closer to the sort of legal question that arose in Eddie Taw, involving therein a point of foreign relations law. In Petrotimor, the "Timor-Gap Treaty" which Australia had entered into was considered non-justiciable before the Australian Federal Court. ${ }^{92}$

\footnotetext{
${ }^{88}$ As Justice Brennan had put it, there is sometimes an 'unusual need for unquestioning adherence' to a political decision which has already been made, or because of the possibility of embarrassment should the state, as a whole, not speak with one voice; Baker v Carr 369 US 186 at 217 per Brennan J. See further L Henkin, Foreign Affairs and the US Constitution (Oxford: Clarendon, $2^{\text {nd }}$ ed, 1996) at 143-148.

${ }^{89}$ E Wilmshurst 'Executive Certificates in Foreign Affairs: The United Kingdom', [1986] 35 ICLQ 157; C Warbrick 'Executive Certificates in Foreign Affairs: Prospects for Review and Control' [1986] 35 ICLQ 13; L Collins 'Foreign Relations and the Judiciary' [2002] 51 ICLQ 485.

${ }^{90}$ Mabo and others v State of Queensland (No 2) (1991) 107 ALR 1 per Brennan J (Mason CJ and McHugh J concurring) at 20; Deane and Gaudron JJ at 58; Dawson J at 92; Toohey $\mathrm{J}$ at 143. For criticism, however, of this decision, see, for example, V Kerruish 'At the Court of the Strange God' (2002) 13 Law and Critique 271 and the other articles appearing in that issue.

${ }^{91}$ [1998] 2 SLR 410 at 423F-H per Yong Pung How CJ (Thean JA and Goh Joon Seng $\mathrm{J}$ concurring). See see $\mathrm{n} 87$ for an extensive treatment of the issue of extraterritoriality arising therein.
}

92 Petrotimor Companhia de Petroleos SARL v Commonwealth of Australia [2003] FCAFC 3 at 15-20, per Black CJ and Hill J applying the principle laid down in England 


\section{THE DENNING LAW JOURNAL}

What makes Eddie Taw the most significant legal case in Singapore's constitutional history, however, is not that the United States, English and Australian courts would probably have steered clear of such an issue today, or that the Singapore High Court went forth and assumed the legal power to strike down Parliament's will, or even that the Court of Appeal, in overturning the decision of Karthigesu JA, accepted the judicial power to do so, even if the Court of Appeal disagreed that this was an instance wherein that judicial power could properly be exercised. Even if the Court of Appeal had struck down, instead, the assumption by the High Court of a constitutional basis for the exercise of such judicial power, constitutionally-speaking the Court of Appeal could only have done so in the course of the Court of Appeal exercising that self-same judicial power which Karthigesu JA had originally relied upon. Parliament, and the Government of the day, did not disagree with any of this.

In sum, the Singapore Courts have claimed the legal power to engage in full-blooded judicial review under the Constitution of the Republic of Singapore, and the various branches of government agree that it is the Court of Appeal that is empowered to say what the Constitution means. There is no doubt that the Court of Appeal got the law right in Eddie Taw. Imagine the disastrous precedent that would have been set had the Court precluded Parliament from legislating on a common crime committed by citizens and permanent residents abroad simply because Parliament wished to also exclude foreigners from the scope of that crime for reasons of international comity. Parliament would have had to override the Court of Appeal in respect of the imposition of Singapore's extraterritorial jurisdiction under a well-recognised and long-established principle of international law. How could Article 12 of the Constitution of the Republic of Singapore have even intended such preclusion in the first place? In this and the Bridges case, the Minister for Law had explained in Parliament that the Government would need to consider whether these judicial incursions would make it difficult to achieve the Government's policies. In relation to Bridges, the Minister had said "we have asked the Attorney-General to give us his considered views because his preliminary review was, and is, that if the law is not amended, then it may render it impossible or well-nigh difficult to enforce the provisions of the Official Secrets Act.” This was said in response to a Parliamentary Member's

in Buttes Gas and Oil Co v Hammer [1982] AC 888 (HL) and distinguishing Kuwait Airways Corporation v Iraqi Airways Co (Nos 4 and 5) [2002] 2 WLR 1353 (HL). 


\section{THE DENNING LAW JOURNAL}

impassioned speech in Parliament on the separation of powers. While the Honourable Minister agreed with the substance of that speech, he was compelled to express the Government's thinking nonetheless that "there may well be a need to amend the Official Secrets Act," and in respect of the Eddie Taw case, amendment may have been required of "the law". ${ }^{93}$ Yet the Government, and Parliament, which has a recent history of seeking ways to install checks against itself, ${ }^{94}$ have ultimately seen fit to invest confidence in the courts. The Government had won Eddie Taw, but lost Bridges. Unlike the aftermath of Chng Suan Tze v Minister of Home Affairs ${ }^{95}$ a decade earlier, neither a single constitutional amendment nor a single legislative amendment resulted.

Popular critics of the Singapore Constitution have for too long dwelt on the exceptional situation in the earlier case of Chng Suan Tze, and have assumed

93 Parliamentary Debates, Official Record, Vol 68, 14 January 1998, cols 90 - 94 (Associate Professor STay) and 96-98 (Professor S Jayakumar).

${ }^{94}$ I have spared extensive discussion of the Presidency, where in fact the President enjoys also a high degree of institutional independence, as well as substantive executive powers unheard of anywhere else in Westminster-style governments. For those unacquainted with Singapore, Parliament amended the Constitution in 1991, thereby turning Singapore's then ceremonial and titular Presidency into an elected office vested with substantive legal powers and immunities. Broadly speaking, these include, but are not limited to, specified powers concerned primarily with the preservation of Singapore's reserves and finances and also the surpluses of statutory board and Government companies, including where necessary the power to override Parliament subject only to popular referendum, and specified powers in respect of key public service appointments; Constitution of the Republic of Singapore (Amendment) Act, No 5 of 1991; Presidential Elections Act, No 27 of 1991; Constitution of the Republic of Singapore (Amendment) Act, No 2 of 1994; Arts 21(2), 22, 22A-I, and also Arts 5(2A), 17(2), 19(2)(g), 37M, 100, 144(2), 144, 148A and G, 151(4), and 151A of the Constitution of the Republic of Singapore. See K Tan 'The Presidency in Singapore: Constitutional Developments' in Tan and Lam (ed) see n 8, 52. A considerable amount has been written on this important aspect of the constitutional separation of powers in Singapore; see Tan and Lam, ibid, and the works cited therein.

95 [1988] SLR 132 at 158B-E per Wee Chong Jin CJ. See see n 77. There was extensive Parliamentary debate wherein the Government stated its reasons for amending the Constitution in respect of a limited class of otherwise 'reviewable' cases: Singapore Parliamentary Debates, Official Record, 25 January 1989, cols 461, 467-471, 531. For a comparative jurisprudence of similar action taken elsewhere in the aftermath of September 11 see the July 2002 issue of the Singapore Journal of Legal Studies. 


\section{THE DENNING LAW JOURNAL}

that because in this one case wherein the Government felt that the decision would hamper its ability to ensure Singapore's security and was compelled (in its view) to seek and achieve a constitutional amendment, the approach approached taken in Chng characterises, in fact, the executive's view more generally of the separation of powers in Singapore. The Minister's speech in the aftermath of the Eddie Taw and Bridges cases points clearly, however, in the other direction. Hard cases make bad law, or in the case of Chng Suan Tze a hard case has resulted in an adverse general impression of the law. On the other hand, nobody could honestly have thought a decade later that the separation of powers was finished in Britain simply because of the controversy over "clause 29" of the much debated Anti-terrorism, Crime and Security Bill which sought to exclude legal proceedings for questioning a certificate or action made or taken by the Secretary of State, or a decision or action of the Special Immigration Appeals Commission (SIAC). The ensuing Part IV of the British Anti-terrorism, Crime and Security Act of 2001 allows review of the Secretary of State's decision by the SIAC instead, seeks to prevent judicial review of the SIAC, makes SIAC a superior court of record, and permits appeals only on a point of law. ${ }^{96}$ The point is that court-watchers should be sufficiently astute to discern the exceptional from the routine. Routinely, as the Minister for Law had also explained, the Singapore Government does face and accept legal losses before the Singapore courts.

The Singapore courts claim the constitutional power in reserve to strike down legislation, which is all the more remarkable here as there is, like the case in the United States, no express provision in the Singapore Constitution which would confer such a power on the courts. This is particularly so in a Westminster-style government, as such a power is something the courts in England do not claim or have but for the dictates of Europe following the Factortame cases. In England, reliance is, by and large, placed on Parliament instead as the essential check. Consider that even Dicey, who explained the doctrine of Parliamentary supremacy only so well, did himself come within a hair's breadth of treason through advocating, against Parliament's will, violent means in respect of Irish Home Rule and you will see what they mean in England. ${ }^{97}$ England, in this regard, is no better or worse, just different. In America, on the other hand, such trust has been placed on the Supreme Court.

\footnotetext{
96 See ss 21, 25, 27 and 35 of the Act and A, $X$ and $Y v$ Secretary of State for the Home Department [2003] HRLR 3 (CA).

${ }^{97}$ Lord Bingham of Cornhill ‘Dicey Revisited’ [2002] Public Law 39 at 43.
} 


\section{THE DENNING LAW JOURNAL}

Yet events there have moved quickly in recent years. Recall that the 1992 United States Presidential Elections was about abortion, and about who would be appointed to the Supreme Court either to preserve or overturn Roe $v$ Wade, depending on which side one was on. Recall too that Roe $v$ Wade itself had involved litigating into existence a liberal solution to the abortion issue. ${ }^{98}$ Eight years on from the 1992 Presidential Elections, a Republican majority in the Court, having learnt judicial activism from a generation of liberal judicial victories, decided in favour of a Republican President for the United States while the minority justices took the view that the Supreme Court should not have heard the case. ${ }^{99}$ Even American liberals today are, therefore, in favour of the common-sense notion that, generally speaking, judges ought not to make the law, they should just apply it. ${ }^{100}$ Perhaps more attention then should be paid to the Israeli experience. There they have an extremely active Supreme Court reminiscent of the heyday of American judicial activism. And yet recent studies show that the Israeli people have simply rejected these judicial overtures. ${ }^{101}$

Worthington's critique of the separation of powers, judicial independence, and the supposedly interventionist legislative record of the executive in Singapore ignores the constitutional dimension to these issues, and it also ignores the fact that it is the constitutional dimension which gives meaning to

\footnotetext{
98410 US 113 (1973).

${ }^{99}$ Bush v Gore Supreme Court of the United States, 12 December 2000.

${ }^{100}$ Professor Dershowitz puts it better than I can: 'Courts ought not to jump into controversies that are political in nature and are capable of being resolved - even if not smoothly or expeditiously - by the popular branches of government. Judges have no special competence, qualifications, or mandate to decide between equally compelling moral claims (as in the abortion controversy) or equally compelling political claims (counting ballots by hand or stopping the recount because the standard is ambiguous). Absent clear governing constitutional principles...these are precisely the sorts of issues that should be left to the rough-and-tumble of politics...': A Dershowitz Supreme Injustice: How the High Court Hijacked Election 2000 (New York: Oxford University Press, 2001) at 194. Liberals had previously continued to cling to the myth of the Supreme Court being 'the least dangerous branch', especially in light of the seemingly moderate position of an emergent "conservative middle group” comprising Justices O’Connor, Kennedy and Souter in the aftermath of the 1992 Presidential Race. This group of three justices had held the balance in Planned Parenthood v Casey, 505 US 833 (1992), a test case for the continuity of Roe, and they had preserved Roe. All three were Republican appointees of the Reagan Administration.

${ }^{101}$ D Barak-Erez 'Judicial Review of Politics: The Israeli Case' (2002) 28 Journal of Law and Society 611.
} 


\section{THE DENNING LAW JOURNAL}

these issues in the first place. In the two cases I have already discussed, Bridges and Eddie Taw, the judiciary and the executive managed to avoid the sorts of situation that we have so often witnessed in the United States or in the famous example in South Africa in the 1950s. I think it is important to ask "what if", in these cases, Parliament, and the Government, had disagreed with the courts? I don't mean to be dramatic, but compare the famous "Cape Coloured voter's case" in which the South African courts struck down the Separate Representation of Voters Act 1951 for infringement of the South Africa Act of 1909. Whatever the legal merits, ${ }^{102}$ the legislature then responded by creating a special appellate court to hear appeals from such judgments. The new appellate court went on to find the decision in the Cape Coloured voters case invalid. Unperturbed, the original court in turn found the legislation creating the new appellate court invalid, and that; therefore, the new court was itself a legal nullity. ${ }^{103}$ Had the South African Government not decided against pursuing the matter any further, the legal system would simply have broken down. ${ }^{104}$ Putting aside such an extreme, but not impossible, example, every-one knows that no

102 On the point of law, drawing a distinction between cases of express constitutional provision and those without see A Bradley 'The Sovereignty of Parliament - in Perpetuity' in J Jowell and D Oliver The Changing Constitution (Oxford: Clarendon, 1989) 25 at 28-29. For the 'new view' of sovereignty see R Latham 'The Law and the Commonwealth: A Jurisprudential Essay' in W Hancock Survey of British Commonwealth Affairs, Volume One (Oxford: Oxford University Press, 1937) 510; G Marshall Constitutional Theory (Oxford: Oxford University Press, 1971) at 40-41 and 52, R Heuston Essays in Constitutional Law (London: Stevens, $2^{\text {nd }}$ ed, 1964) Chapter 1. The 'new view' suggests that even at common law in England, where there is an unwritten constitution and Parliament reigns supreme, the courts could review an Act on the basis of some flaw in the composition and procedure of Parliament. This is not the English courts' view of the common-law: British Railways Board v Pickin [1974] AC 765. The common British academic view, however, is that Parliament could impose limits upon itself as to the manner and form of legislation. See also the Factortame cases see $\mathrm{n} 75$.

${ }^{103}$ Harris v Dönges [1952] 1 TLR 1245 sub nom Harris v Minister of the Interior 1952 (2) SA 428; also Minister of the Interior $v$ Harris 1952 (4) SA 769. The affair is described in G Marshall Parliamentary Sovereignty and the Commonwealth (Oxford: Oxford University Press: 1957).

${ }^{104}$ Hart, see n 29 at 119. 
government which is constantly at odds with itself is in any sense ideal. ${ }^{105}$ Lord Devlin could have spoken for just about everyone where he once said: "The British have no more wish to be governed by judges than they have to be judged by administrators". ${ }^{106}$

I have focused on the superior judiciary and the position of the AttorneyGeneral under the Constitution. I have sought to capture the "spirit" which informs the everyday, practical meaning of the Singapore Constitution. Dr Worthington's attack is, if I might say so, so inept in respect of the Constitution itself and what it means that if his criticisms could amount to anything at all, they could only have hit the mark here. Yet they do not. No Constitution is perfect. Equally, however, no Constitution can properly be understood by way of empirical surveys of the opinions of its critics.

\footnotetext{
${ }^{105}$ For a recent, and important, contribution to this debate in relation to Singapore, and also the independence of the subordinate judiciary, see Hor, see $n 34$, whose arguments here I am largely in agreement with.

${ }^{106}$ The Times, October 27, 1976. Or as Ellesmere is reported to have once said in rebuke of Lord Coke: 'He doth as much as insinuate that this court is all sufficient in itself to manage the state...', Sir William Holdsworth, History of English Law, Volume 5 (London: Methuen, 1938), at 430.
} 
THE DENNING LAW JOURNAL 